Case Report

\title{
Membranous nephropathy associated with hepatitis C virus infection treated with corticosteroids and Ledipasvir-Sofosbuvir: a case report and review of literature
}

\author{
Qinjie Weng ${ }^{1}$, Xiao $\mathrm{Li}^{1}$, Hong Ren ${ }^{1}$, Jingyuan Xie ${ }^{1}$, Xiaoxia Pan ${ }^{1}$, Jing $\mathrm{Xu}^{1}$ and Nan \\ Chen ${ }^{1}$ \\ ${ }^{1}$ Department of Nephrology, Ruijin Hospital, Shanghai Jiaotong University School of Medicine, Shanghai, China \\ Correspondence to: Nan Chen, email: cnrj100@126.com \\ Keywords: hepatitis C virus, membranous nephropathy, hepatitis C virus-related glomerulonephritis, Ledipasvir-Sofosbuvir, case \\ report \\ Received: October 02, $2016 \quad$ Accepted: January 25, $2017 \quad$ Published: February 16, 2017
}

\section{ABSTRACT}

Background: Membranous nephropathy (MN) is the most common cause of nephrotic syndrome in adults. As many clinical cases have reported, it may be associated with hepatitis C virus (HCV) infection. Antiviral therapy can be various.

Case summary: We report a case of patient with chronic HCV infection and MN, who presented with was proteinuria. He was treated with ledipasvir and sofosbuvir (Harvoni; Gilead Sciences, Foster City, CA) and was found to be virus-free.

Conclusion: We have reported this case to provide insight into whether Ledipasvir-Sofosbuvir should be administered for HCV-related glomerulonephritis.

\section{INTRODUCTION}

Hepatitis $\mathrm{C}$ virus (HCV) infection is an important cause of chronic liver disease. Besides liver function impairment, it can lead to extrahepatic manifestations including kidney disease, such as membranous nephropathy $(\mathrm{MN})$ [1-3].

Treatment of HCV-related $\mathrm{MN}$ is various, but no recommendation is provided. Antiviral therapy, which includes Interferon- $\alpha$ (INF- $\alpha$ ) and ribavirin, is effective in clearing $\mathrm{HCV}$ infection in some patients [3-5]. In 2015, a new oral regimen is available for HCV patients. Ledipasvir-Sofosbuvir (Harvoni; Gilead Sciences, Foster City, CA) is a combination tablet and is recommended for patients with genotype $1[6,7]$.

Here, we report a case of membranous nephropathy associated with $\mathrm{HCV}$ infection treated with ledipasvir and sofosbuvir, corticosteroid, and cytotoxic agent.

\section{CASE REPORT}

A 65-year-old male patient was found to have proteinuria during a health checkup in 2014. He underwent a surgery for encephalic angioma and received massive blood transfusion in 1992. Besides, he had received a diagnosis of chronic HCV infection for 10 years. He was admitted to another hospital at first in January, 2015.
Physical examination showed trace pitting edema of the lower extremities. The initial laboratory evaluation was significant for proteinuria of $2980 \mathrm{mg} / 24 \mathrm{~h}$, serum albumin of $21 \mathrm{~g} / \mathrm{L}$ and HCV RNA viral load of $6.53 * 10^{\wedge} 5$ (copies). His HCV genotype was $1 \mathrm{~b}$. A renal biopsy was performed there, with histopathology consistent with membranous nephropathy. Light microscopy showed 15 glomeruli and one was global sclerotic. Thickened glomerular capillary walls were found. Tubulointerstitial lesion was mild. Immunofluorescence microscopy revealed diffuse granular capillary wall deposits of $\operatorname{IgG}[\operatorname{IgG} 1(++), \operatorname{IgG} 2(-), \operatorname{IgG} 3$ $( \pm), \operatorname{IgG} 4(+++)], \operatorname{IgM}, \mathrm{C} 3$. They recommended to treat $\mathrm{HCV}$ infection first.

From April 10, the patient was started on LedipasvirSofosbuvir (1\#, qd) for 3 months. In the end of April, the patient presented to our hospital with progressive foamy urine. On admission, the patient's consciousness was clear. Physical examination showed severe edema of lower extremities. Blood pressure was $143 / 76 \mathrm{mmHg}$ and no clinical chest or abdominal abnormalities were found. Laboratory investigation revealed the following: serum creatinine $121 \mu \mathrm{mol} / \mathrm{L}, \quad$ eGFR ${ }_{\text {CKD-EPI }} 54 \mathrm{ml} / \mathrm{min} / 1.73 \mathrm{~m}^{2}$, proteinuria $12169 \mathrm{mg} / 24 \mathrm{~h}$, serum albumin $13 \mathrm{~g} / \mathrm{L}$. Urinalysis was remarkable for protein (4+) and 31-50 red blood cells/high-power field (HPF). Complement factors, such as $\mathrm{C} 3, \mathrm{C} 4$, serum immunoglobulins and rheumatoid factor were in the normal range. Anti-dsDNA antibodies, anti-nuclear antibodies, and antineutrophil 
Table 1: Laboratory data of the patient

\begin{tabular}{|c|c|c|c|c|c|}
\hline & Biopsy & 3 months & 7 months & 12 months & 20 months \\
\hline Creatinine $(\mu \mathrm{mol} / \mathrm{L})$ & 94 & 119 & 84 & 90 & 84 \\
\hline Proteinuria (mg/24h) & 2980 & 12169 & 2258 & 1346 & 763 \\
\hline Albumin (g/L) & 21 & 13 & 26 & 36 & 41 \\
\hline Hemoglobin $(\mathrm{g} / \mathrm{L})$ & 144 & 134 & 110 & 129 & 124 \\
\hline \begin{tabular}{|l|} 
Urinalysis \\
\end{tabular} & 1 & Protein $(4+)$ & Protein $(3+)$ & Protein $(4+)$ & Protein $(2+)$ \\
\hline $\begin{array}{l}\text { HCV RNA viral load } \\
\text { (copies) }\end{array}$ & $6.53 * 10^{\wedge} 5$ & Negative & / & Negative & l \\
\hline Autoimmunity & Normal & Normal & Normal & Normal & 1 \\
\hline
\end{tabular}

cytoplasmic antibodies were absent. HCV RNA viral load (Roche, COBAS AmpliPrep/COBAS TaqMan HCV Test) was already negative. Main laboratory findings were summarized in Table 1. Chest CT revealed a small amount of pleural effusion in the left side.

His pathology slides were read again: light microscopy revealed a total of 16 glomeruli, 2 of which were global sclerotic. Suspicious eosinophilic deposits were found in epithelial side in Masson staining. A diffuse thickening of glomerular basement membrane was seen with increased mesangial matrix and mesangial cells (Figure 1). Tubulointerstitial lesion was mild. These features were consistent with MN. Besides, HCV antibody was found to be negative in kidney tissues.

Steroid pulse therapy $(40 \mathrm{mg} / \mathrm{d}$ of methylprednisolone intravenously) was initiated for 3 days, then tapered to $40 \mathrm{mg} / \mathrm{d}$ of prednisolone orally with $200 \mathrm{mg} / \mathrm{d}$ of Cyclosporine A. By then, he had been on Ledipasvir-Sofosbuvir for about 3 weeks. Also, he was treated with urokinase $(50000 \mathrm{U} / \mathrm{d})$ for anticoagulation, Plavix for antiplatelet aggregation, along with Caltrate D, Rabeprazole, etc. During follow-ups, HCV RNA (COBAS) remained negative, meanwhile, serum creatinine decreased to normal $(84 \mu \mathrm{mol} / \mathrm{L})$, proteinuria gradually decreased to $763 \mathrm{mg} / 24 \mathrm{~h}$, and serum albumin increased to $41 \mathrm{~g} / \mathrm{L}$, thus prednisolone and Cyclosporine A were gradually reduced. (Figure 2)

\section{DISCUSSION}

This is a case of membranous nephropathy associated with HCV infection. The patient was treated with Ledipasvir-Sofosbuvir, followed with prednisolone and Cyclosporine A. To our knowledge, no such case was reported before.

The incidence of HCV infection has been reported to be about 3-4 million per year and it is known that 3\% of the world's population-210 million people - is currently infected with HCV [4]. Meanwhile, HCV prevalence in the Chinese population was $1.6 \%$. Annual incidence of HCV in China was 6.01 per 100,000 [8]. Almost 40\% of patients with $\mathrm{HCV}$ develop at least one extrahepatic manifestation during the course of the disease, including kidney disease [9]. The prevalence of HCV infection was higher in hemodialysis patients than that in the general population of China [10].

Although Membranoproliferative glomerulonephritis (MPGN) is most commonly associated with $\mathrm{HCV}$ infection [11], other glomerulonephritis are also

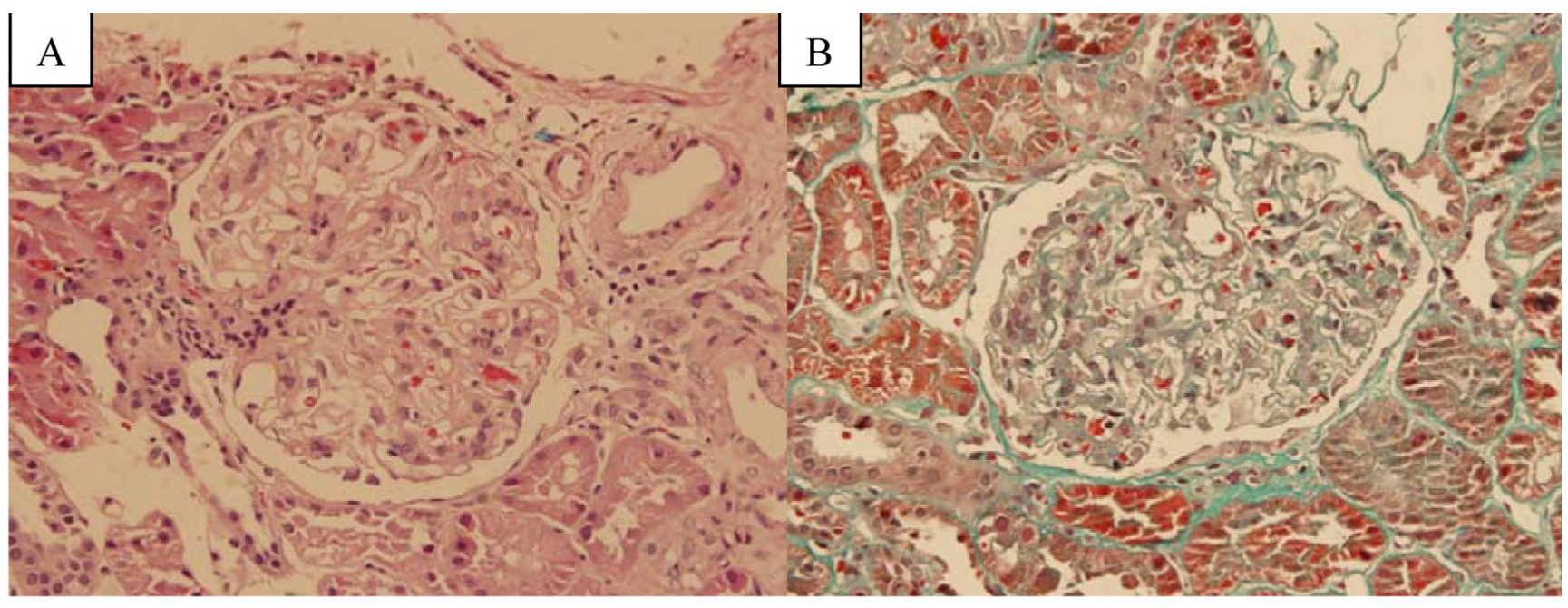

Figure 1: Kidney biopsy with light microscopy. A. hematoxylin-eosin stain $(\times 400)$. B. Masson stain $(\times 400)$. 
reported to be associated with $\mathrm{HCV}$, including $\mathrm{MN}$, focal segmental glomerulosclerosis (FSGS), postinfectious glomerulonephritis, IgA nephropathy, and fibrillary or immunotactoid glomerulopathy [12]. Yamabe et al [13] found that $8.3 \%$ of $\mathrm{MN}$ patients were anti-HCV-positive or HCV RNA-positive. The pathogenesis of $\mathrm{MN}$ in these patients may be related to the deposition of immune complexes containing HCV proteins in glomeruli, like HBV infection[14]. The clinical manifestation and histological findings of $\mathrm{HCV}$-associated $\mathrm{MN}$ are similar to that of idiopathic $\mathrm{MN}$.

The optimal therapy for HCV-associated glomerulonephritis is still not very clear $[3,15,16]$. The evidence on treatment of HCV-related kidney disease comes predominantly from IFN-based therapies [5]. By literature review, we found two case reports of patients with HCV-associated glomerulonephritis, presented with deterioration of kidney function and proteinuria. [17, 18] Treatment with INF-2a (one plus ribavirin) resulted in sustained virological response with a clinical remission of proteinuria as well as stabilization of renal function. Thus, we suggest that anti-virus therapy could ameliorate proteinuria in patients with $\mathrm{HCV}$ related glomerulonephritis.

Antiviral therapy, aiming for eradication and reduction of $\mathrm{HCV}$-related antibodies and immune complexes, includes Interferon- $\alpha$ (IFN- $\alpha$ ), Ribavirin, etc. It remains a main therapy in $\mathrm{HCV}$-related glomerulonephritis [15]. The main treatment goal for HCV-infection is to achieve an undetectable HCV RNA level, which is known as sustained virological response (SVR), and is usually measured 12 weeks after completion of therapy [19]. Achieving SVR is considered a virological cure, as more than $99 \%$ of patients remain free from the virus when followed up for 5 years after completing therapy [19]. In the meta-analysis by Feng et al [20], antiviral treatment was found to decrease proteinuria in HCVpositive CKD patients. That is, the decrease in proteinuria following antiviral therapy was associated with HCV-RNA clearance.

Ledipasvir-Sofosbuvir is one of the newly discovered antiviral therapy, which was approved by the FDA on October 10, 2014, for the treatment of HCV infection. It is a novel, once-daily, fixed-dose combination antiviral agent that has shown high SVR rates in HCVinfected patients[6]. It contains both ledipasvir (an $\mathrm{HCV}$ NS5A inhibitor) and sofosbuvir (an NS5B polymerase inhibitor) and is the first anti-HCV therapy that does not require the coadministration of interferon or ribavirin $[6$, 7, 21].

Ledipasvir and sofosbuvir are both direct-acting antiviral agents [22]. Sofosbuvir is a liver-targeted nucleotide prodrug of the active triphosphate GS-461203, which has been approved for use in HCV genotypes 1-4. It acts as an inhibitor of the HCV NS5B RNA-dependent RNA polymerase, which works like a chain terminator $[23,24]$. Ledipasvir is an NS5A inhibitor that is effective in genotypes $1 \mathrm{a}, 1 \mathrm{~b}, 4 \mathrm{a}$ and $5 \mathrm{a}$, and is also effective in genotypes $2 \mathrm{a}$ and $3 \mathrm{a}$ with relatively lower activity. The mechanism is still unclear, but one possible mechanism is that it inhibits hyperphosphorylation of NS5A, which is required for viral production. NS5A inhibitors may also lead to faulty viral assembly by redistributing the subcellular localization of the protein. The NS5A and NS5B inhibitors demonstrate an additive effect when used in combination [22].

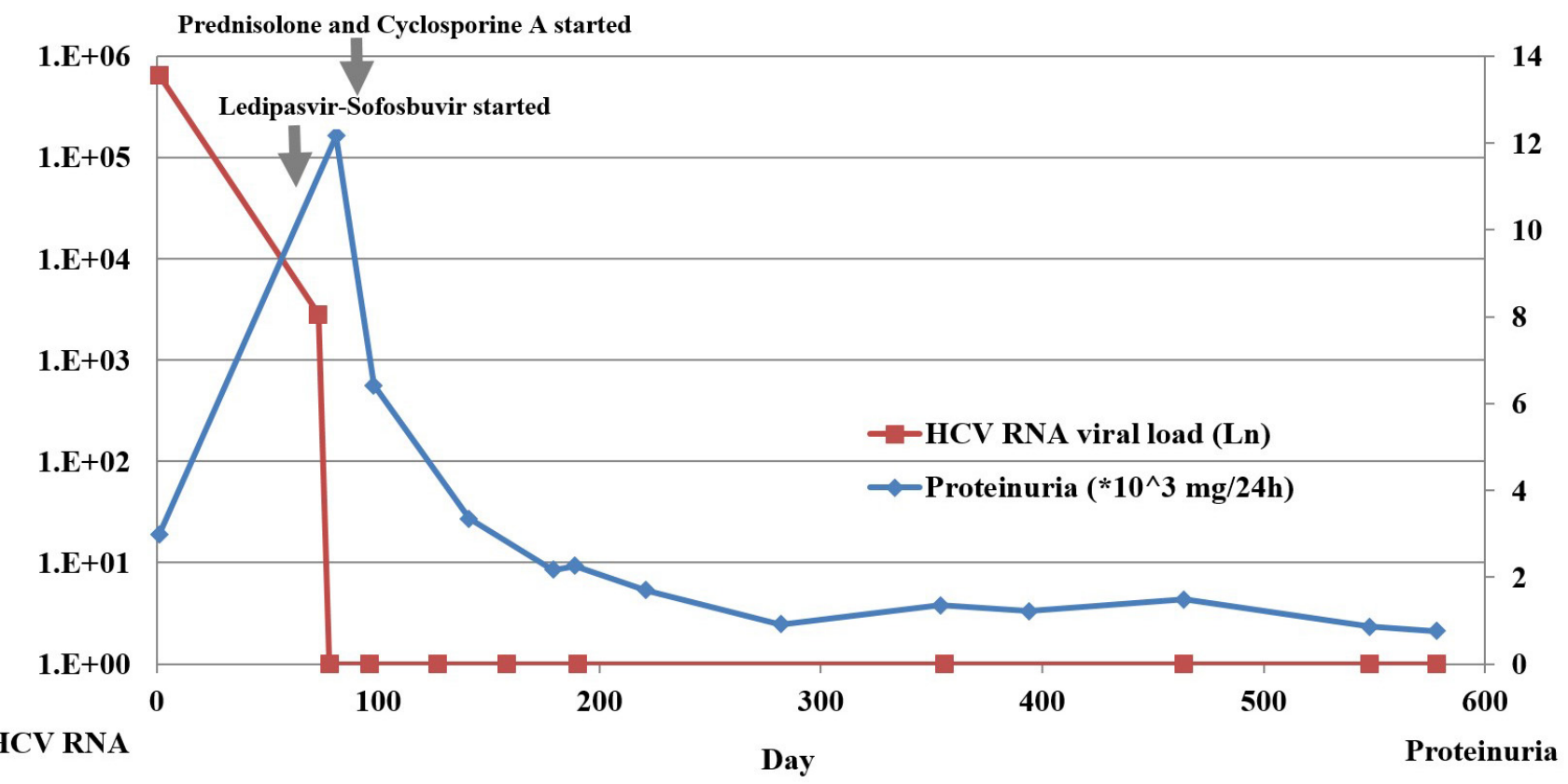

Figure 2: HCV RNA viral load and proteinuria at disease onset and during follow-ups. 
Several studies about Ledipasvir-Sofosbuvir were carried out recently, all of which showed positive results. Afdhal [25] found that once-daily of LedipasvirSofosbuvir with or without RBV for 12 or 24 weeks was highly effective in patients with HCV genotype 1 infection who are treatment naïve. Kowdley [26] concluded that once-daily of Ledipasvir-Sofosbuvir for 8 weeks was associated with a high rate of SVR among treatment naïve patients with $\mathrm{HCV}$ genotype 1 infection without cirrhosis. Meanwhile, they found that the inclusion of ribavirin in the regimen and the extension of the duration of treatment to 12 weeks were not associated with additional benefit. The study of Gane [27] in New Zealand showed that the combination of ledipasvir and sofosbuvir is highly effective in patients with $\mathrm{HCV}$ genotype 1 infection who are treatment naïve or did not respond to previous treatment.

The most common adverse events observed in clinical trials $[25,26,28]$ with Ledipasvir-Sofosbuvir were headache, fatigue, nausea, and insomnia. Hematologic abnormalities also occurred in some patients, including mild-to-moderate hyperbilirubinemia, transient and asymptomatic lipase elevations, and a mean hemoglobin change of $-0.2 \mathrm{~g} / \mathrm{dL}$ to $-0.6 \mathrm{~g} / \mathrm{dL}$ from baseline. Maximum plasma concentrations (Tmax) of ledipasvir were observed 4 to 4.5 hours post oral administration with a terminal half-life (t1/2) of $47 \mathrm{~h}$. Sofosbuvir undergoes intracellular activation and ultimately becomes GS331007 , a predominant circulating metabolite, which has peak plasma concentrations of 3.5 to 4 hours and a halflife of $27 \mathrm{~h}[29$ ]. No obvious nephrotoxicity was observed in patients using Ledipasvir-Sofosbuvir. However, we do find a case report [30] of Ledipasvir-Sofosbuvir associated biopsy-proven acute interstitial nephritis (AIN). As Ledipasvir is eliminated in the feces, whereas the majority of sofosbuvir is cleared by the kidney, patients with CKD who have impaired excretion may experience a prolonged exposure of its metabolites and delayed recovery of renal function [31]. Sofosbuvir-containing regimens are not currently recommended for patients with estimated Glomerular Filtration Rate (eGFR) less than $30 \mathrm{ml} / \mathrm{min}$. Currently, dose recommendations cannot be given for patients with advanced renal disease [32]. Further studies in larger cohorts and improvements in safety and efficacy are needed for patients with renal disease. Therefore, physicians need to be aware of the potential side effect of this agent.

Regarding to the present case, this is a patient with chronic $\mathrm{HCV}$ infection and nephrotic syndrome. It is usually difficult to design treatment for these patients since steroids can exacerbate $\mathrm{HCV}$ infection and lead to inferior results. As can be seen in this case, antiviral therapy (Ledipasvir-Sofosbuvir) followed by steroids and cytotoxic agent can not only reduce urinary protein, improve hypoproteinemia, relieve edema, but also effectively prevent virus reactivation and further aggravation of $\mathrm{HCV}$ infection. Therefore, in this case, Ledipasvir-Sofosbuvir shows positive effect and ensures the safety of the following steroids treatment. However, due to the side effects of steroids and antiviral therapy, physicians should still be cautious with the treatment in case of any complication.

\section{CONCLUSIONS}

We have reported a case of membranous nephropathy with HCV infection. The patient was treated with Ledipasvir-Sofosbuvir for antiviral therapy, along with prednisolone and Cyclosporine A. He remained free from virus and his proteinuria was gradually reduced during follow-up for 20 months even after stopping Ledipasvir-Sofosbuvir. We believe this case report provides some insight into whether Ledipasvir-Sofosbuvir should be administered for glomerulonephritis with $\mathrm{HCV}$ infection.

\section{CONFLICTS OF INTEREST}

The authors have no financial or personal conflicts of interest to disclose.

\section{REFERENCES}

1. Kamar N, Izopet J, Alric L, Guilbeaud-Frugier C and Rostaing L. Hepatitis C virus-related kidney disease: an overview. Clin Nephrol. 2008; 69:149-160.

2. Meyers CM, Seeff LB, Stehman-Breen CO and Hoofnagle JH. Hepatitis C and renal disease: an update. American journal of kidney diseases. 2003; 42:631-657.

3. Morales JM, Kamar N and Rostaing L. Hepatitis C and renal disease: epidemiology, diagnosis, pathogenesis and therapy. Contributions to nephrology. 2012; 176:10-23.

4. Ozkok A and Yildiz A. Hepatitis C virus associated glomerulopathies. World journal of gastroenterology. 2014; 20:7544-7554.

5. Fabrizi F, Martin P, Cacoub P, Messa P and Donato FM. Treatment of hepatitis C-related kidney disease. Expert Opin Pharmacother. 2015; 16:1815-1827.

6. Gritsenko D and Hughes G. Ledipasvir/Sofosbuvir (harvoni): improving options for hepatitis $\mathrm{C}$ virus infection. P T. 2015; 40:256-276.

7. Gilead Sciences I. Harvoni (ledipasvir/sofosbuvir) prescribing information. http://wwwgileadcom/. 2014.

8. Bennett H, Waser N, Johnston K, Kao JH, Lim YS, Duan ZP, Lee YJ, Wei L, Chen CJ, Sievert W, Yuan Y and Li $\mathrm{H}$. A review of the burden of hepatitis $\mathrm{C}$ virus infection in China, Japan, South Korea and Taiwan. Hepatol Int. 2015; 9:378-390

9. Cacoub P, Renou C, Rosenthal E, Cohen P, Loury I, Loustaud-Ratti V, Yamamoto AM, Camproux AC, 
Hausfater P, Musset L, Veyssier P, Raguin G and Piette JC. Extrahepatic manifestations associated with hepatitis $\mathrm{C}$ virus infection. A prospective multicenter study of 321 patients. The GERMIVIC. Groupe d'Etude et de Recherche en Medecine Interne et Maladies Infectieuses sur le Virus de l'Hepatite C. Medicine (Baltimore). 2000; 79:47-56.

10. Li $\mathrm{H}$ and Wang SX. Hepatitis $\mathrm{C}$ viral infection in a Chinese hemodialysis unit. Chin Med J (Engl). 2010; 123:35743577.

11. D'Amico $\mathrm{G}$ and Fornasieri A. Cryoglobulinemic glomerulonephritis: a membranoproliferative glomerulonephritis induced by hepatitis $\mathrm{C}$ virus. American journal of kidney diseases. 1995; 25:361-369.

12. Sumida K, Ubara Y, Hoshino J, Suwabe T, Nakanishi S, Hiramatsu R, Hasegawa E, Hayami N, Yamanouchi M, Sawa N, Takemoto F, Takaichi K and Oohashi K. Hepatitis $\mathrm{C}$ virus-related kidney disease: various histological patterns. Clin Nephrol. 2010; 74:446-456.

13. Yamabe H, Johnson RJ, Gretch DR, Fukushi K, Osawa H, Miyata M, Inuma H, Sasaki T, Kaizuka M, Tamura N and et al. Hepatitis $\mathrm{C}$ virus infection and membranoproliferative glomerulonephritis in Japan. J Am Soc Nephrol. 1995; 6:220-223.

14. Appel GB and Appel GB. Immune-complex glomerulonephritis - deposits plus interest. New England Journal of Medicine. 1993; 328:505-506.

15. Latt N, Alachkar N, Gurakar A, Latt N, Alachkar N and Gurakar A. Hepatitis C virus and its renal manifestations: a review and update. Gastroenterology \& Hepatology. 2012; 8:434-445.

16. Stehman-Breen C, Alpers CE, Couser WG, Willson R and Johnson RJ. Hepatitis C virus associated membranous glomerulonephritis. Clin Nephrol. 1995; 44:141-147.

17. Shah $\mathrm{HH}$ and Patel C. Long-term response to peginterferon in hepatitis $\mathrm{C}$ virus-associated nephrotic syndrome from focal segmental glomerulosclerosis. Renal failure. 2013; 35:1182-1185.

18. Fabrizi F, Fogazzi GB, Cresseri D, Passerini P, Martin P, Donato MF, Rumi MG and Messa P. Antiviral therapy for HCV-associated cryoglobulinemic glomerulonephritis: case report and review of the literature. Kidney \& blood pressure research. 2012; 35:687-693.

19. Hepatitis C guidance: AASLD-IDSA recommendations for testing, managing, and treating adults infected with hepatitis C virus. Hepatology. 2015; 62:932-954.

20. Feng B, Eknoyan G, Guo ZS, Jadoul M, Rao HY, Zhang $\mathrm{W}$ and Wei L. Effect of interferon-alpha-based antiviral therapy on hepatitis $\mathrm{C}$ virus-associated glomerulonephritis: a meta-analysis. Nephrol Dial Transplant. 2012; 27:640646.
21. Floreani A. Perspectives of fixed daily dose of sofosbuvir and ledipasvir for the treatment of chronic hepatitis C. Expert Opin Pharmacother. 2015; 16(6):801-804.

22. Pawlotsky JM. NS5A inhibitors in the treatment of hepatitis C. J Hepatol. 2013; 59:375-382.

23. Gilead Sciences I. Sovaldi (sofosbuvir) prescribing information. http://wwwgileadcom/. 2014.

24. Sofia MJ. Beyond sofosbuvir: what opportunity exists for a better nucleoside/nucleotide to treat hepatitis C? Antiviral Res. 2014; 107:119-124.

25. Afdhal N, Zeuzem S, Kwo P, Chojkier M, Gitlin N, Puoti M, Romero-Gomez M, Zarski JP, Agarwal K, Buggisch P, Foster GR, Brau N, Buti M, et al. Ledipasvir and sofosbuvir for untreated HCV genotype 1 infection. The New England journal of medicine. 2014; 370:1889-1898.

26. Kowdley KV, Gordon SC, Reddy KR, Rossaro L, Bernstein DE, Lawitz E, Shiffman ML, Schiff E, Ghalib R, Ryan M, Rustgi V, Chojkier M, Herring R, et al. Ledipasvir and sofosbuvir for 8 or 12 weeks for chronic HCV without cirrhosis. The New England journal of medicine. 2014; 370:1879-1888.

27. Gane EJ, Stedman CA, Hyland RH, Ding X, Svarovskaia E, Subramanian GM, Symonds WT, McHutchison JG and Pang PS. Efficacy of nucleotide polymerase inhibitor sofosbuvir plus the NS5A inhibitor ledipasvir or the NS5B non-nucleoside inhibitor GS-9669 against HCV genotype 1 infection. Gastroenterology. 2014; 146:736-743.

28. Afdhal N, Reddy KR, Nelson DR, Lawitz E, Gordon SC, Schiff E, Nahass R, Ghalib R, Gitlin N, Herring R, Lalezari J, Younes ZH, Pockros PJ, et al. Ledipasvir and sofosbuvir for previously treated HCV genotype 1 infection. The New England journal of medicine. 2014; 370:1483-1493.

29. German P, Mathias A, Brainard D and Kearney BP. Clinical Pharmacokinetics and Pharmacodynamics of Ledipasvir/ Sofosbuvir, a Fixed-Dose Combination Tablet for the Treatment of Hepatitis C. Clinical pharmacokinetics. 2016; 55:1337-1351.

30. Wanchoo R, Thakkar J, Schwartz D and Jhaveri KD. Harvoni (Ledipasvir With Sofosbuvir)-Induced Renal Injury. The American journal of gastroenterology. 2016; 111:148-149.

31. Bunchorntavakul C, Maneerattanaporn $\mathrm{M}$ and Chavalitdhamrong D. Management of patients with hepatitis $\mathrm{C}$ infection and renal disease. World journal of hepatology. 2015; 7:213-225.

32. Fazel Y, Lam B, Golabi P and Younossi Z. Safety analysis of sofosbuvir and ledipasvir for treating hepatitis C. Expert opinion on drug safety. 2015; 14:1317-1326. 